\title{
Assessment of Road Side Snacks' Microbiological Qualities in Ilese-Ijebu Southwestern Nigeria: Implications on Packaging and Bioaerosol Monitoring
}

\author{
Adegbite A. Ayoade*1 \\ Salako S. Gbolahan² \\ Sowole Ayodele $\mathbf{R}^{3}$ \\ ${ }^{* 1}$ Department of Water and Sanitation Technology, \\ ${ }^{2}$ Department of Environmental Health Sciences, \\ ${ }^{3}$ Department of Medical Laboratory Techniques
}

Ogun State College of Health Technology, P.M.B 2081 ljebu Ode Nigeria

(aagbite@yahoo.co.uk)

This journal is licensed under a Creative Commons Attribution-NonCommercial 4.0 International License (CC-BY-NC).

Articles can be read and shared for noncommercial purposes under the following conditions:

- BY: Attribution must be given to the original source (Attribution)

- NC: Works may not be used for commercial purposes (Noncommercial)

This license lets others remix, tweak, and build upon your work non-commercially, and although their new works must also acknowledge you and be non-commercial, they don't have to license their derivative works on the same terms.

License Deed Link: http://creativecommons.org/licenses/by-nc/4.0/

Legal Code Link: http://creativecommons.org/licenses/by-nc/4.0/legalcode

$A B C$ Research Alert uses the CC BY-NC to protect the author's work from misuse.

\section{Abstract}

The study was carried out to determine the microbiological contamination of three common snacks (Puff-Puff, Fried Cake Bean, and Fried Potato) consumed at Ilese-Ijebu Southwestern Nigeria and to determine the effect of the packaging materials on the contamination of the snacks. The study made used of two different types of packaging materials, the ones used by the food vendors and sterile plastic bags for control to transport the samples to the laboratory for analysis. The detections of pathogenic microorganisms were carried out using laboratory standard procedures for culturing by MacConkey Agar. The results of laboratory analyses showed that all the snacks samples collected with vendors packaging materials were contaminated with one or more of Escherichia coli, Klebsiella pneumonia, and Staphylococcus aureus, as result of old newspapers, students' old notes used as the packaging materials coupled with poor food vendors' hygiene practices. On the other hand, the snacks collected by the sterile plastic bags contained a few of the microorganisms that might be as results of contamination during food handling and bioaerosol presence around where the foods were prepared and served to customers. The study concluded that there is the need for educative and public awareness about the potential ingestion and health problems associated with consumption of the snacks with unclean packaging materials. The regulatory governmental agencies like NAFDAC should be actively involved in making sure food consumed by the people do not constitute health hazard and risks to the consumers.

\section{Keywords}

Ilese-Ijebu,Microbiology,Nigeria,Pathogenic,Snack 


\section{INTRODUCTION}

Street foods are "ready-to-eat" foods and beverages prepared and sold by vendors and hawkers especially in the street and other similar public places (FAO, 1997). Street foods are extremely heterogeneous food category, encompassing meals, drinks, and snacks. They also show great variation in terms of ingredients, methods of retail, processing and consumption and are sold on the street from "pushcarts or baskets or balance poles, or from stalls or shops having fewer than four permanent walls" (FAO, 2007).

Furthermore, Street food is available in a public place, such as from a vendor on a street. Typically, street food is tasty, ready-to-eat food or drink sold on the street, in a market, park or other public place (Street Food Institute, 2015). Some street foods are regional but many are not, having spread beyond their place of origin and enjoyed locally for their exotic or unusual ingredients and flavors. Most street foods are considered both finger food and fast food and are more reasonably priced than restaurant meals. 2.5 billion People worldwide eat street food every day, according to a 2007 Food and Agriculture Organization study (Street Food Institute, 2015).

Unfortunately, most handlers of street food in the developing countries are ignorant of basic food safety measures, with poor hygiene and environmental and poor sanitary conditions (Oyelana and Coker, 2012), (Tortoe, et al., 2013), (Kok and Balkaran, 2014), and (Alimi, 2016). Consequently, street foods are commonly exposed to various contaminants at different stages of handling (Rane, 2011) and (Sudershan, Kumar, Kashinath, Bhaskar, and Polasa, 2012).

However, Street-vended food provide a major source of income for a vast number of persons, particularly women; a chance for self-employment and the opportunity to develop business skills with low capital investment; least expensive and most accessible means of obtaining a nutritionally balanced meal outside the home for many low income people (Madueke, Awe, and Jonah, 2014), (WHO, 2002) and (Dipeolu, et al., 2007).

Despite the economic and nutritional benefits of street foods, the consumption of these roadside foods has been suggested to potentially increase the risk of food borne diseases as street foods are readily contaminated from different sources (Tambekar et al., 2008) and studies have revealed the frequent contamination of street food in many developing world including Nigeria. Furthermore, food is one of the environmental media or components that allow exchange of microorganisms (Gordon, 1998). Therefore, food safety, food sanitation, food protection and food processing among others are the concern of Environmental health that addresses all human-health-related aspects that form integral part of public health. However, the present study was carried out to determine the effects of packaging materials on potential contamination of the snacks consumed in the study area.

Therefore, the study was carried out to assess the microbiological qualities of snacks consumed in the study area Ilese-Ijebu, where people especially students, finding the snacks cheap and accessible and by using two different packaging materials to collect the snacks (Puff-Puff, Bean Cake and Fried Potatoes)- the old-used papers and sterile plastic bags, determine the public health implications of consuming these snacks prepared and bought along the road sides by the students of the Ogun State College of Health Technology, the residents and commuters that patronize various spots on the daily basis as a case study. 


\section{OBJECTIVE OF THE STUDY}

The aim of this research work is to examine the microbiological qualities of roadside snacks consumed among people of Ilese-Ijebu Ogun State Southwestern Nigeria and to address the following specific objectives in the course of the study:

a) To examine the pathogenic microorganisms' contamination in the selected roadside snacks consumed among the residents (Puff Puff, Bean Cake (Akara), Fried Potato) using two different packaging materials.

b) To determine if packaging materials affect the microbiological qualities of the snacks by comparing the results obtained from used papers by the vendors and the sterile plastic bags provided by the researchers.

\section{BRIEF INFORMATION ABOUT THE STUDY AREA}

The study area is a relatively a small town Ilese -Ijebu located in Ijebu-North East Local Government Area of Ogun State Nigeria, on Latitude $6.8012^{\circ} \mathrm{N}$, and longitude $3.9531^{\circ} \mathrm{E}$. The old Ondo-Benin Road passes through the town and serves as pass-by access road to Lagos -Shagamu-Benin Expressway that link the west and eastern part of the country. The presence of the first higher institution in the state, Ogun State College of Health Technology, attracts increasing population of students yearly.

\section{MATERIALS AND METHODS}

The study involved standards procedures for collection of snacks, preserve them and transport them to Nutrition and Dietetics laboratory of the College to make sure the qualities between the collection points and laboratory identification and isolation of the pathogenic microorganisms were not altered.

\section{PROCEDURES FOR THE SNACK FOOD COLLECTION}

Two sets of snack (Puff-puff, Bean cakes and Fried Potatoes) were purchased from ten (10) vendors by the road sides and those hawking from Ilese-Ijebu Ijebu North East Local Government Area of Ogun state Southwest Nigeria. Samples were randomly purchased from different vendors without specific order. One set of the samples were stored in sterile plastic bags and the other sets, the researchers allowed the vendors to wrap the snacks with the packaging materials the vendors have. The two sets of the samples were adequately labeled, transported and kept in the laboratory refrigerators of Nutrition and Dietetics Department of the College for analysis within two to three hours of purchase.

\section{PROCEDURES FOR LABORATORY ANALYSIS}

The two sets of snacks the one wrapped by used papers by the vendors and the one collected with sterile plastic bags were prepared under the same aseptically conditions to prevent recontamination . Few samples from each snacks (puff-puff, bean cakes, fried potatoes) were cut and placed in universal bottle containing peptone water, shaken well for the food samples to dissolve and the solution kept in the refrigerator to maintain the qualities of the collected food before introducing the prepared samples into the agar media for incubation (Andrew and Hammack, 2003). 
Then, from the department of Medical Laboratory Techniques of the College where two MacConkey Agar and Chocolate Agar media were prepared using standard procedures and the contents from the universal bottles inoculated in the agars to detect and isolate any potentials pathogenic microorganisms (Chessborough, 2007), (Zohreh, et.al., 2015) and (Oje, et.al., 2016)

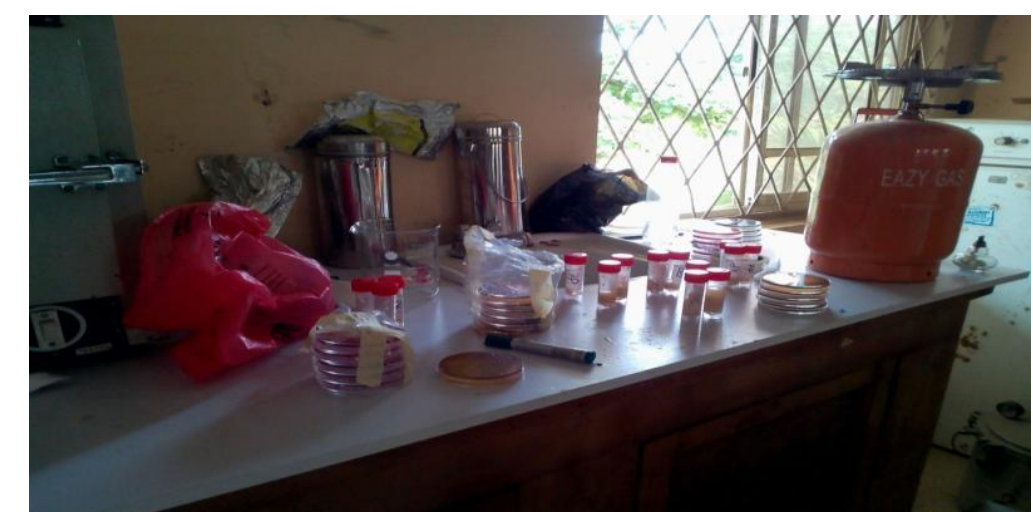

Figure 1: Laboratory Analysis procedures at Microbiology Laboratory of the College (Source: Authors, 2016)

\section{DATA COLLECTION AND ANALYSIS}

The analyses were carried out in triplicate. From each sample, three (3) samples were collected from one each and the laboratory analysis procedures were carried out on each sample. Simple descriptive statistics of tables and chart were used to display and analyzed the results of the laboratory and to compare the results from the two different packaging for the samples.

\section{RESULTS AND DISCUSSIONS}

Results are presented, displayed in the sections containing the results of the laboratory analysis for the two set of samples from the different packaging materials and the comparison of the results.

\section{Results Of The Analysis With Vendors Packaging Materials}

From the laboratory analysis, the three main pathogenic microorganisms were isolated and found in the three food samples. They are Escherichia coli, Klebsiella pneumonia and Staphylococcus aureus.

The tables follow contain the results of presence and absence of the three common pathogenic microorganisms detected and isolated. The figures in the tables showed the numbers of samples that contained the Escherichia coli Klebsiella pneumonia and Staphylococcus aureus. However, the figures shown in the tables are the total number of the snack samples contained various microorganisms out of ten (10) bought from different vendors.

Comparison of the Packaging Materials and Detection of Microorganisms by the MacConkey Agar

\begin{tabular}{|l|c|c|c|c|c|c|}
\hline & \multicolumn{3}{|c|}{ Vendors Packaging Materials } & \multicolumn{3}{c|}{ Sterile Polythene Bags } \\
\hline & $\mathbf{S}_{\mathbf{1}}$ & $\mathbf{S}_{\mathbf{2}}$ & $\mathbf{S}_{\mathbf{3}}$ & $\mathbf{S}_{\mathbf{1}}$ & $\mathbf{S}_{\mathbf{2}}$ & $\mathbf{S}_{\mathbf{3}}$ \\
\hline Escherichia coli & $\mathbf{7}$ & $\mathbf{2}$ & $\mathbf{N D}$ & $\mathbf{N D}$ & $\mathbf{1}$ & $\mathbf{N D}$ \\
\hline Klebsiella pneumonia & $\mathbf{3}$ & ND & $\mathbf{2}$ & ND & ND & $\mathbf{1}$ \\
\hline Staphylococcus aureus. & $\mathbf{2}$ & ND & ND & ND & ND & ND \\
\hline
\end{tabular}

Table 1: Showing the comparison of results of Puff-Puff Contamination

S1 (1st Cut sample), S2 (2nd Cut sample), S3 (2nd Cut sample), (ND) No Microorganisms detected 
The table 1, 2 and 3 showing the contamination of the snacks (puff -puff, bean cakes, and fried potatoes) collected from ten (10) different with vendors packaging materials and compared with the results with the sterile polythene bags. The results in table 1 showed that the detection and isolation by MacConkey Agar medium, from the three (3) cut samples from the puff-puff samples, two (2) contained Escherichia coli, two (2) samples also have Klebsiella pneumonia and one (1) has Staphylococcus aureus microorganisms.

\begin{tabular}{|l|c|c|c|c|c|c|}
\hline & \multicolumn{3}{|c|}{ Vendors Packaging Materials } & \multicolumn{3}{c|}{ Sterile Polythene Bags } \\
\hline & $\mathbf{S}_{\mathbf{1}}$ & $\mathbf{S}_{\mathbf{2}}$ & $\mathbf{S}_{\mathbf{3}}$ & $\mathbf{S}_{\mathbf{1}}$ & $\mathbf{S}_{\mathbf{2}}$ & $\mathbf{S}_{\mathbf{3}}$ \\
\hline Escherichia coli & $\mathbf{6}$ & $\mathbf{3}$ & $\mathbf{N D}$ & $\mathbf{1}$ & $\mathbf{1}$ & ND \\
\hline Klebsiella pneumonia & $\mathbf{1}$ & $\mathbf{N D}$ & $\mathbf{2}$ & ND & ND & $\mathbf{1}$ \\
\hline Staphylococcus aureus. & $\mathbf{1}$ & $\mathbf{1}$ & $\mathbf{1}$ & ND & ND & ND \\
\hline
\end{tabular}

Table 2: Showing the comparison of results of Bean cake (Akara) Contamination S1 (1st Cut sample), S2 (2nd Cut sample), S3 (2nd Cut sample), (ND) No Microorganisms detected

On the other hand, with sterile plastic bags collection, only one out of the three samples (3) sample showed presence of Escherichia coli, one (1) sample also have Klebsiella pneumonia and none of the samples has Staphylococcus aureus microorganisms as shown in table 1 above.

Furthermore, the results in table 2 contained the numbers of the detection and isolation of microorganisms in the bean cakes collected with vendors packaging materials by the MacConkey Agar medium and that of the sterile plastic bags. From the three (3) cut samples from the sample, Escherichia coli, detected from two (2) cut samples, two samples also contained Klebsiella pneumonia and the three samples have Staphylococcus aureus microorganisms. On the other hand, with the sterile polythene bag, two of the three samples showed presence of Escherichia coli, one sample contained both Klebsiella pneumonia and while none of the samples have Staphylococcus aureus. microorganisms.

\begin{tabular}{|l|c|c|c|c|c|c|}
\hline & \multicolumn{3}{|c|}{ Vendors Packaging Materials } & \multicolumn{4}{c|}{ Sterile Polythene Bags } \\
\hline & $\mathbf{S}_{\mathbf{1}}$ & $\mathbf{S}_{\mathbf{2}}$ & $\mathbf{S}_{\mathbf{3}}$ & $\mathbf{S}_{\mathbf{1}}$ & $\mathbf{S}_{\mathbf{2}}$ & $\mathbf{S}_{\mathbf{3}}$ \\
\hline Escherichia coli & $\mathbf{2}$ & $\mathbf{1}$ & $\mathbf{N D}$ & $\mathbf{N D}$ & $\mathbf{N D}$ & ND \\
\hline Klebsiella pneumonia & ND & ND & $\mathbf{1}$ & ND & ND & $\mathbf{1}$ \\
\hline Staphylococcus aureus. & ND & ND & ND & ND & ND & ND \\
\hline
\end{tabular}

Table 3: Showing the comparison of results of Fried Potatoes Contamination

S1 (1st Cut sample), S2 (2nd Cut sample), S3 (2nd Cut sample), (ND) No Microorganisms detected

The figures in table 3 contained the numbers of fried potatoes samples with microorganisms. The samples cultured from vendor packaging materials using the MacConkey Agar medium indicated that two (2) cut samples contaminated with Escherichia coli, one sample contained Klebsiella pneumonia, while one (1) sample has Staphylococcus aureus. microorganisms. On the other hands, one (1) cut sample contaminated with Escherichia coli, (1) sample contained Klebsiella pneumonia while none of the samples had Staphylococcus aureus microorganisms.

\section{SUMMARY OF THE MICROORGANISMS" DETECTION BY THE TWO PACKAGING MATERIALS}

The sections contained enumeration and comparison of the detection of microorganisms by both the vendors packaging materials and the sterile polythene bags, by counting the number of snacks containing one or more of the pathogenic microorganisms. 


\begin{tabular}{|l|c|c|c|c|c|c|}
\hline & \multicolumn{3}{|c|}{ Vendors Packaging Materials } & \multicolumn{3}{c|}{ Sterile Polythene Bags } \\
\hline & Puff-Puff & Baked Beans & Fried Potato & Puff-Puff & Baked Beans & Fried Potato \\
\hline Escherichia coli & $\mathbf{9}$ & $\mathbf{9}$ & $\mathbf{5}$ & $\mathbf{1}$ & $\mathbf{2}$ & $\mathbf{0}$ \\
\hline Klebsiella pneumonia & $\mathbf{5}$ & $\mathbf{3}$ & $\mathbf{3}$ & $\mathbf{1}$ & $\mathbf{1}$ & $\mathbf{1}$ \\
\hline Staphylococcus aureus. & $\mathbf{2}$ & $\mathbf{3}$ & $\mathbf{1}$ & $\mathbf{0}$ & $\mathbf{0}$ & $\mathbf{0}$ \\
\hline
\end{tabular}

Table 4: Showing the summary of all the Snacks Contamination

The results in table 4 above show that, all the snacks samples collected with vendors packaging materials were contaminated with more than one of the microorganisms detected.

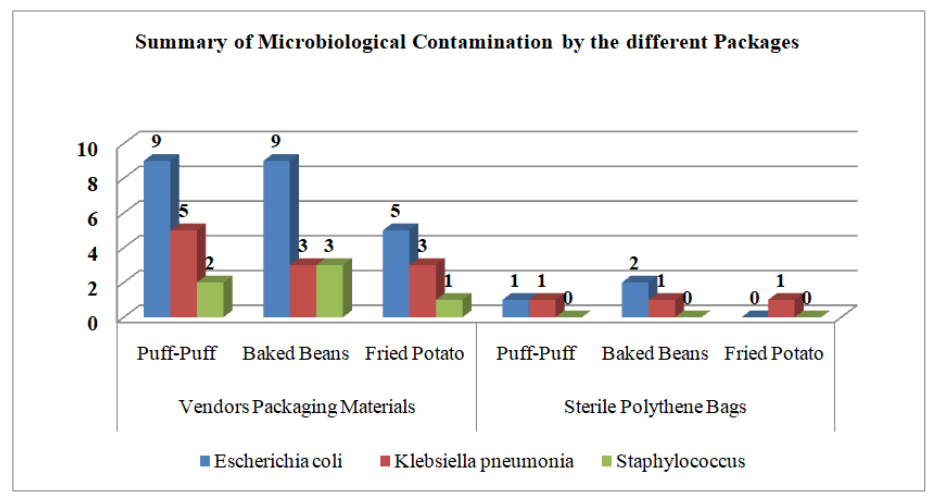

Figure 2: Showing the Summary of Microbiological Contamination

Out of ten (10) samples of Puff-Puff, nine (9) had Escherichia coli contamination, Klebsiella pneumonia were isolated from five (5) samples, while Staphylococcus aureus. isolated from two samples of the ten Puff-Puff collected for the study. On the other hands, with the sterile polythene bags, the contaminations were highly reduced, one (1) puff sample had Escherichia coli contamination, Klebsiella pneumonia were isolated from one (1) sample and while no Staphylococcus aureus. isolated from the sample of the ten (10) Puff-Puff samples collected by the sterile polythene bags.
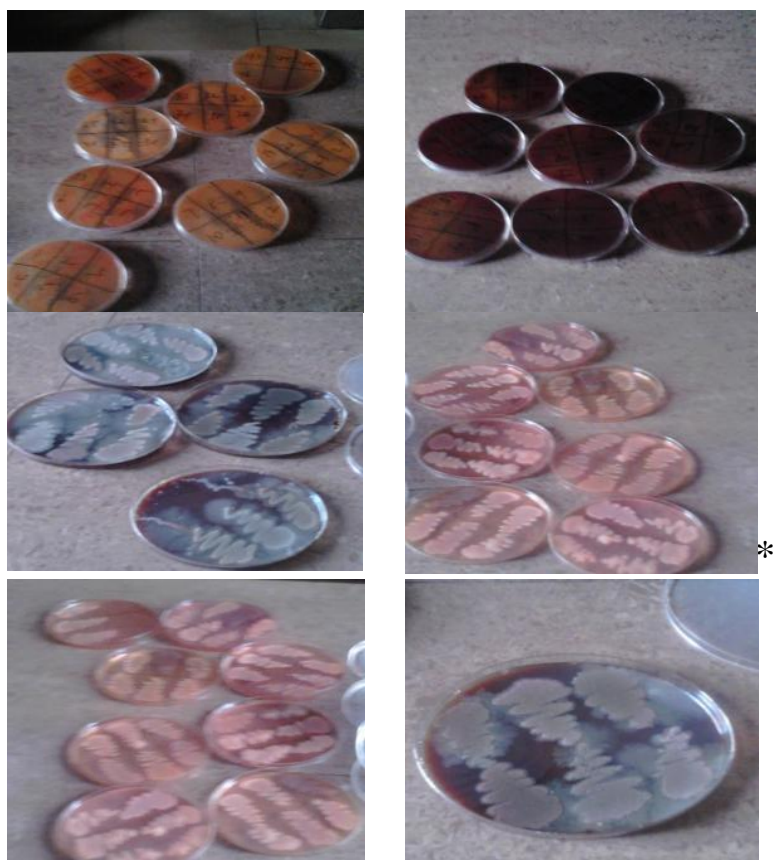

* Some of the results from blood agar medium used to compliment the analysis from MacConkey Agar

Figure 3: Showing some of the pictures of pathogenic microorganisms detected Source: (Authors, 2016) 


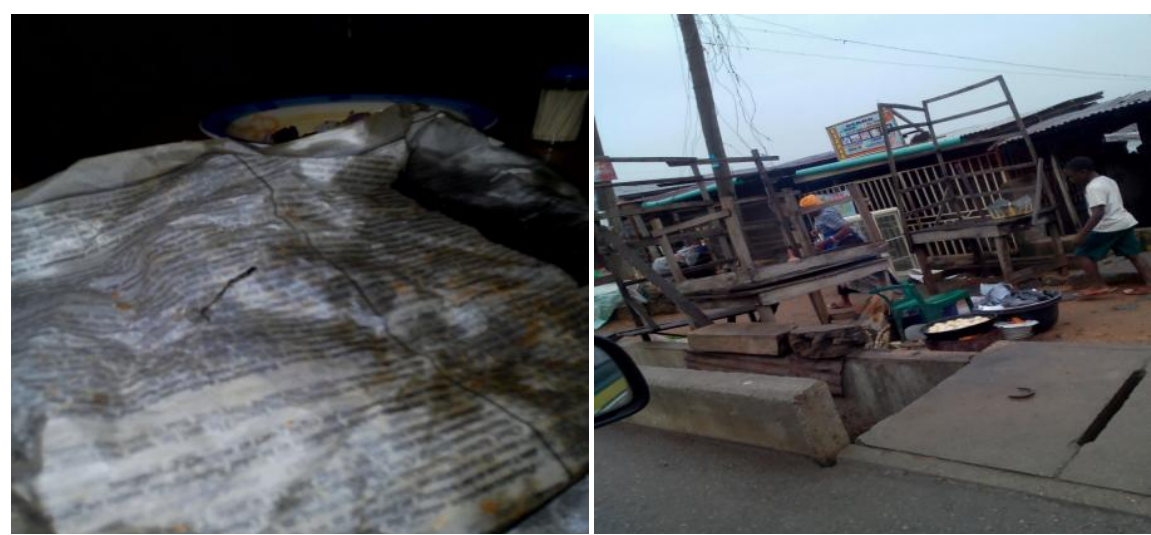

Figure 4: Showing used old newspaper for wrapping and vendor spot where puff-puff are prepared and sold closed to channel and main road Source: (Authors, 2016)

However, results of contamination of Bean cake with the microorganisms showed nine samples (9) out ten (10) collected with vendors packaging materials had Escherichia coli, three (3) contained Klebsiella pneumonia, and also three (3) of the bean cakes samples had Staphylococcus aureus. . Then, the results of sterile polythene bags packaging indicated the detection and isolation of Escherichia coli in seven (2) of the samples, one (1) sample contained Klebsiella pneumonia and none contaminated with Staphylococcus aureus. .

Then, the results of the last snacks samples Fried Potatoes showed that five samples (5) had Escherichia coli, three (3) contained Klebsiella pneumonia, and one (1) of the fried potatoes samples had Staphylococcus aureus. using the vendor packaging materials. On the contrary, no Escherichia coli were detected and isolated in any of the samples, likewise Staphylococcus aureus. . But two (2) samples contained Klebsiella pneumonia.

\section{DISCUSSIONS}

The high presence of some pathogenic microorganisms namely Escherichia coli, Klebsiella pneumonia and Staphylococcus aureus. , that can be identified and isolated showed that many factors are in play viz-a-viz the human and environmental factors. The issues of human factor attributed to the vendors' poor handling and hygiene practices and an indication of sanitation (Bennett and Lancette, 2016). These were observed during the collection of the food items, the vendors do not tidy up their environment, water used for washing the potatoes not changed when dirty, when the batter for the puff-puff put in the oil for frying and mixing of bean paste for bean cakes can result into contamination. The results of the study are supported by the work of Madueke, et al., ( 2014), where samples of street foods: fried yam, fried potato, fried plantain, akara, fish and suya retailed in two locations along Lokoja-Abuja express road were analyzed for their microbial load. The samples analysed contained pathogenic microorganisms - Bacillus cereus, Staphylococcus aureus. aureus, Klebsiella pseudomonas among others. In similar study carried out by Monday, et.al.,(2014), they also assessed the microbiological quality of ready-to-eat foods (rice and moimoi) sold by vendors in Federal Polytechnic, Bali campus, Taraba State. Similarly with this study, the microorganisms isolated included Staphylococcus aureus. aureus, Escherichia coli, Klebsiella spp among others. Another explanation for the contamination was the type and "sanitary" conditions of the packaging materials used by the vendors either out of ignorance or attempt to minimize the cost of production and maximize their profits by sourcing for old 
newspaper, students old notes, even in some cases students assignment and project reports were identified to be used for the wrapping and packing of the snacks, might probably serve as source of the contaminants, as this has been identified by the Oje, et.al., (2016). Even the study carried out by Yeboah-Manu, et.al., (2010), showed that pathogenic bacteria are the most common known causes of food contamination and food borne illnesses where the microorganisms are detected in ready-to-eat foods being sold in the open (street foods) and those from restaurants on the university of Ghana campus and (Odu and Ameweiye, 2013) reported that in Port Harcourt Metropolis Nigeria, Fish, a staple food is readily contaminated with microorganisms, indications of the poor hygiene practices among the food handlers.

Furthermore, the implications of using of old, unkempt newspaper and old note from students showed that of microorganisms found in the snacks are sourced from them because the results of analysis of using sterile polythene bags sharply in contrast from the results of using the vendor packaging materials. It should be noted that the presence some of the pathogenic microorganisms like Klebsiella pneumonia that can be found in the mouth, skin, and intestinal tract, where it initially does not cause disease, which according to MicrobeWiki (2016), the Klebsiella pneumonia can progress into severe bacterial infections leading to pneumonia, bloodstream infections, wound infections, urinary tract infections, and meningitis. Unfortunately, some of these vendors do blow air into polythene bags to create space, to open them to keep the snacks after wrapping them with old newspaper and used student notes. Also, the presence of Staphylococcus aureus a type of bacteria commonly found on the skin and hair as well as in the noses and throats of people and animals (Foodsafety.gov, 2016). Therefore, the chance of the microorganisms getting into the snacks is high when the vendors and the customers sneeze, blow their noses or blow air into the polythene bags to open them (The University of Utah, 2011) and (Acheampong, 2015) among others.

The other implication of detecting microorganisms in the food samples could be as a result of the presence of bioaerosol around where the snacks were prepared, handled and served. For instance, Staphylococci are ubiquitous known to be found in air, dust, sewage, water, environmental surfaces, humans and animal (Nyenje and Ndip, 2013). Though, the study did not make any attempt to monitor the airborne microorganism but the environmental conditions around where the snacks were prepared, handled and served can promote their incidence and multiplication (Alvarez, Buttner, \& Stetzenbach, 1995), (Jensen, Schafer, \& CIH, 1998) and (Jahne, et al., 2016) among others.

\section{CONCLUSION}

The study concluded that, apart from poor food handling and personal hygiene, packaging materials for the snacks in the study areas and elsewhere coupled with vendors and consumers' poor attitudes towards food safety are sources of pathogenic microorganisms. Therefore, there should be a further research to assess other microorganisms (fungi and helminthes), assessment of human exposures to these pathogenic microorganisms associated with the snacks, educative and public awareness about the potential ingestion and health problems associated with consumption of the contaminated snacks and the regulatory governmental agencies like NAFDAC should be actively involved in making sure food consumed by the people are not constituting health hazard and risks to the inhabitants/consumers. 


\section{References}

Acheampong, B. E. (2015). Assessment of food hygiene practices by street food vendors and microbial quality of selected foods sold. A Study at Dunkwa-On-Offin, Upper Denkyira East Municipality of the Central Region. (Thesis). Kwame Nkrumah University of Science and Technology.

Retrieved from <http://dspace.knust.edu.gh:8080/jspui/handle/123456789/7058>

Alimi, B. A. (2016). Risk factors in street food practices in developing countries: A review. Food Science and Human Wellness. doi:10.1016/j.fshw.2016.05.001

Alvarez, A. J., Buttner, M. P., \& Stetzenbach, L. D. (1995). PCR for Bioaerosol Monitoring: Sensitivity and Environmental Interference. Applied and Environmental Microbiology, 61(10), 3639-364. doi:0099-2240/95/\$04.0010

Andrews, W. H., \& Hammack, T. S. (2003). BAM: Food sampling/preparation of sample homogenate. Retrieved July 19, 2016, from U.S. Food and Drug Administration http://www.fda.gov/Food/FoodScienceResearch/LaboratoryMethods/ucm063335.htm

Bennett, R.W and Lancette, G A (2016) BAM: Staphylococcus aureus Bacteriological Analytical Manual Chapter 12 https://www.fda.gov/Food/FoodScienceResearch/LaboratoryMethods/ucm071429.htm

Cheesbrough, M. (2005). District laboratory practice in tropical countries, part 2 Second edition. Retrieved from <http://fac.ksu.edu.sa/sites/default/files/Book-District_Laboratory_Practice_in_Tropical_Countries_Par $\mathrm{t}-2 \_$Monica_Cheesbrough.pdf>

Dipeolu, A. O., Akinbode, S. O., \& Okuneye, P. A. (2007). Income Generating Potentials of Street Food Vending Businesses in Ogun State, Nigeria. An International Journal ASSET Series. 2 (1): 180-189.

FAO (2009) Good Hygienic Practices in the Preparation and Sale of Street Food in Africa. Tools for training

FAO (2007) Promises and Challenges of the informal food sector in developing countries

FAO (1997) Street foods (FAO food and nutrition paper) - Alimentation de rue (Étude FAO alimentation et nutrition) - Alimentos que se venden en la vía pública (Estudio FAO alimentación y nutrición)

Foodsafety.gov. (2016). Staphylococcus aureus. -Food Poisoning. Retrieved July 22, 2016, from U.S. Department of Health \& Human Services, https://www.foodsafety.gov/poisoning/causes/bacteriaviruses/Staphylococcus aureus. /

Gordon, L. (1998). Some Components of Environmental Health and Protection Systems. Retrieved from <http://hslic.unm.edu/resources/spc/docs/gordon/Some_Components_of_Environmental_Health_and_P rotection_S.pdf>

Jahne, M., Rogers, S., Holsen, T., Grimberg, S., Ramler, I. \& Kim, S. (2016). Bioaerosol deposition to food crops near manure application: Quantitative microbial risk assessment. Journal of environmental quality., 45(2), 666-74. Retrieved from <http://www.ncbi.nlm.nih.gov/pubmed/27065414>

Jensen, P. A., Schafer, M. P., \& CIH, P. (1998). NIOSH manual of analytical methods J. Sampling and Characterization Of Bioaerosols. Retrieved from https://www.cdc.gov/niosh/docs/2003-154/pdfs/chapter-j.pdf

Kok, R., \& Balkaran, R. (2014). Street food vending and hygiene practices and implications for consumers. Journal of Economics and Behavioral Studies, 6(3), 188-193. Retrieved from http://www.ifrnd.org/Research\%20Papers/J6(3)3.pdf

Madueke, S. N., Awe, S., \& Jonah, A. I. (2014). Microbiological Analysis of Street Foods Along Lokoja-Abuja Express Way, Lokoja. 2(1), .Retrieved from <http://www.usa-journals.com/wp-content/uploads/2014/01/Madueke_Vol21.pdf>

MicrobeWiki. (2016). Klebsiella pneumoniae pathogenesis. Retrieved July 22, 2016, from https://microbewiki.kenyon.edu/index.php/Klebsiella_pneumoniae_pathogenesis

Monday, I. E., Francis, J. I. \& Mohammad, S. U.( 2014)Microbiological Quality of Ready-To-Eat Foods (Rice and Moimoi) Sold By Food Vendors in Federal Polytechnic Bali, Taraba State Nigeria. Journal of Environmental Science, Toxicology And Food Technology Volume 8, Issue 2 PP 145-149

Nyenje, M. E., \& Ndip, R. N. (2013). The challenges of foodborne pathogens and antimicrobial chemotherapy: A global perspective. Afr. J. Microbiol. Res., 7(14), 1158-1172. doi:10.5897/ajmrx12.014

Odu, N. N., \& Ameweiye, N. B. (2013). Microbiological quality of Street-Vended-Ready-To-Eat "Bole" fish in Port Harcourt Metropoplis. New York Science Journal, 6(2), .Retrieved from <http://www.sciencepub.net/newyork/ny0602/015_16354ny0602_92_101.pdf〉

Oje, O., David, O., Adeosun, O., Adebayo, A., \& Famurewa, O. (2016). Multiple antibiotic-resistant Escherichia coli in ready-to-eat foods from food outlets in Ekiti state university and its Environ. British Microbiology Research Journal, 13(1), 1-11. doi:10.9734/bmrj/2016/23477 
Oyelana, O. A., \& Coker, A. A. (2012). Microbial contamination at different stages of production of Ogi in Mowe: A rural community, southwest, Nigeria. Bacteriology Journal, 2: 1-11.. doi:10.3923/bj.2012.1.11

Rane, S. (2011). Street Vended food in developing world: Hazard analyses. 51(1), Retrieved from <http://www.ncbi.nlm.nih.gov/pmc/articles/PMC3209856/>

Street Food Institute. (2015). What is street food? Retrieved July 19, 2016, from <http://www.streetfoodinstitute.org/what-is-street-food/>

Sudershan, R. V., Kumar, N. R., Kashinath, L., Bhaskar, V \& Polasa, K. (2012). Microbiological hazard identification and exposure assessment of poultry products sold in various localities of Hyderabad, India. Retrieved from http://www.ncbi.nlm.nih.gov/pmc/articles/PMC3347783/

Tambekar, D. H., Jaiswal, V., Dhanorkar, D., Gulhane, P \& Dudhane, M. (2008). Identification of Microbiological hazards and Safety of ready-to-eat food vended streets of Amravati City, India. Journal of Applied Biosciences., 7, 195-201.

The University of Utah. (2011). Food Handling Guide-Environmental Health and Safety. Retrieved July 22, 2016, from The University of Utah, The University Of Utah Environmental Health and Safety < https://ehs.utah.edu/general-safety/food-handling-guide>

Tortoe, C., Johnson, N. T., Ottah-Atikpo, M., \& Tomlins, K. I., (2013). Systematic approach for the management and control of food safety for the street/informal food sector in Ghana. Food and Public Health, 3(1), 59-67. Retrieved from http://article.sapub.org/10.5923.j.fph.20130301.07.html

World Health Organization. (2002). Safer food for better health. Retrieved from <http://apps.who.int/iris/bitstream/10665/42559/1/9241545747.pdf>

Yeboah-Manu, D., Kpeli, G., Akyeh, M., \& Bimi, L. (2010). Bacteriological Quality of Ready-to-Eat Foods Sold on and Around University of Ghana Campus. Research Journal of Microbiology, 5, 130-136. doi:10.3923/jm.2010.130.136

Zohreh, M., Ali, M. L., Ali, E., Ashkan, I., \& Ayub, E. F. (2015). Microbiological quality of ready-to-eat foods of Tehran province. African Journal of Food Science, 9(5), 257-261. doi:10.5897/ajfs2015.1260 